УДК 616.37-002-089.168-036.8:[316.621+613.7+330.59+159.942

DOI 10.11603/2414-4533.2016.4.7191

(С) В. В. ЛЕОНОВ, В. М. ЧУМАКОВ, Н. А. МАЮРА, О. О. ПЕРЕРВА ${ }^{1}$

Сумський державний університет

Комунальна установа "Сумська міська клінічна лікарня № 5"1

\title{
Оцінка якості життя у паціентів із гострим панкреатитом після операційного лікування
}

\author{
V. V. LEONOV, V. M. CHUMAKOV, N. A. MAIURA, O. O. PERERVA ${ }^{1}$ \\ Sumy State University \\ Municipal Institution "Sumy City Clinical Hospital № 5"1
}

\section{LIFE QUALITY ASSESSMENT IN PATIENTS WITH ACUTE PANCREATITIS AFTER SURGICAL TREATMENT}

Гострий панкреатит - це актуальна проблема сучасної медицини, різноманітність проявів якої стає не тільки випробуванням для пацієнта, але й складним завданням для лікарів різних спеціальностей. Адже захворювання не тільки вимагає усіх зусиль під час операційного лікування, а й залишає по собі зміни, які суттєво впливають на соматичні та психічні аспекти здоров'я людини. Метою дослідження було вивчення якості життя хворих після операційного лікування гострого панкреатиту. Отримані дані дають чітке уявлення про віддалені наслідки захворювання, які не піддаються визначенню лабораторними або інструментальними методами.

Acute pancreatitis is an actual problem of modern medicine, a variety of its manifestations is not only a problem for the patient, but also a hard task for the doctors of different specialities. After all, the disease not only requires all the efforts during the surgical treatment, but leaves behind such local and systemic changes that have a significant effect on somatic and mental aspects of human health. The aim of the investigation was to study the quality of life of patients after surgical treatment of acute pancreatitis. The findings give a clear idea about the long-term consequences of the disease, which can not be defined by laboratory or instrumental methods.

Постановка проблеми і аналіз останніх досліджень та публікацій. Гострий панкреатит гостре асептичне запалення підшлункової залози (П3) демаркаційного типу, в основі якого лежить ферментна аутоагресія ліполітичними та активованими протеолітичними ферментами з подальшим аутолізом панкреатоцитів та залученням у процес навколишніх тканин черевної порожнини та заочеревинного простору, а також комплексу органних систем позаочеревинної локалізації $[3,5]$.

Гострий панкреатит (ГП) є актуальною проблемою сучасної абдомінальної хірургії. В Україні захворюваність на гострий панкреатит складає 102 на 100000 населення, загальна летальність при гострому панкреатиті коливається у межах 4-15\%, а при некротичних формах складає 24-60 \%, післяопераційна летальність - до 70$80 \%$. Основним контингентом хворих на ГП є люди працездатного віку. Серед хворих, що вижили, 55-73 \% залишаються інвалідами. Таким чином, ГП $є$ актуальною проблемою сучасної абдомі- нальної хірургії, яка спричиняє істотні соціальні та економічні збитки [1, 5, 7-9].

Останнім часом зростає інтерес до гострого панкреатиту не тільки як до патологічного процесу в підшлунковій залозі та суміжних органах, але і як до хвороби, що може призвести до змін якості життя пацієнтів, особливо після проведення операційних втручань, оскільки основною метою діяльності лікаря є підтримка і продовження життя та збільшення можливостей пацієнтів після проведеного лікування. Знизити якість життя пацієнтів може як сам патологічний процес у підшлунковій залозі та за ї̈ межами, так і обсяг операційних втручань та їх наслідки. Реакція на захворювання формується за рахунок стану систем психологічної адаптації та факторів, зумовлених самим захворюванням, і методів його лікування $[2,6]$.

Мета роботи: оцінка якості життя пацієнтів із гострим панкреатитом після проведення різних типів операційного лікування для обгрунтування комплексного підходу до тактики хірургічного лікування та подальшої реабілітації. 
Матеріали і методи. На основі добровільної інформованої згоди було проведено психодіагностичне обстеження 79 пацієнтам, які перебували на стаціонарному лікуванні та були оперовані з приводу гострого панкреатиту на базі комунальної установи “Сумська міська клінічна лікарня № 5” у період з 2010 до 2015 р. 27 пацієнтів із зазначеної групи були прооперовані з використанням міні-інвазивних технологій. 62 пацієнти - чоловіки, 17 жінки. Середній вік складав $(36,7 \pm 12,2)$ року. Вік та стать пацієнтів достовірно не відрізнялись і не брались до уваги при даному дослідженні. Обстеження з метою визначення якості життя проводили не раніше ніж через 2 місяці після виписування зі стаціонару шляхом активного виклику на амбулаторне обстеження.

Якість життя пацієнтів досліджували за допомогою Методики оцінки якості життя хворих та інвалідів (NAIF) [4], що включає такі показники: фізична мобільність (ФМ), емоційний стан (ЕС), сексуальна функція (СФ), соціальний статус (СоцС), пізнавальна функція (ПФ), економічний стан (ЕкС). Сума даних показників визначає інте- гральний показник (ІП). У людини зі збереженими функціями, яка задоволена усіма гранями свого життя, ІП якості життя дорівнює 100 \% або наближений до цієї величини. Незначне зниження якості життя - ІП $\geq 75$ \%, помірне - ІП 50-75 \%, різке - ІП 25-50 \%, різко виражене - IП $\leq 25 \%$.

Групу порівняння склали 80 практично здорових людей без гострого панкреатиту та операційних втручань в анамнезі віком від 25 до 45 років.

Статистичний аналіз даних дослідження проводили за допомогою програми "Microsoft Office Excel”. Середні значення наведено із стандартним відхиленням $\mathrm{M} \pm \sigma$. Достовірність оцінювали за допомогою критерію Стьюдента (t). Достовірною вважали різницю показників при коефіцієнті p $\leq 0,05$.

Результати досліджень та їх обговорення. При визначенні якості життя пацієнтів за допомогою тесту NAIF було виявлено низькі показники якості життя у пацієнтів, оперованих з приводу гострого панкреатиту, відносно контрольної групи. Результати аналізу якості життя представлено в таблиці 1.

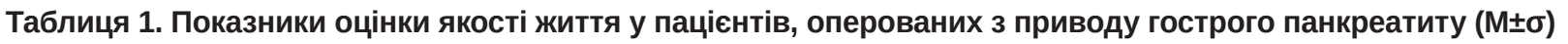

\begin{tabular}{|c|c|c|c|c|c|c|c|}
\hline \multirow{2}{*}{$\begin{array}{c}\text { Пацієнти з гострим } \\
\text { панкреатитом }\end{array}$} & \multicolumn{7}{|c|}{ Показники якості життя, \% } \\
\hline & $\Phi \mathrm{M}$ & $\mathrm{EC}$ & СФ & СоцС & ПФ & ЕкС & ІП \\
\hline $\begin{array}{l}\text { Оперовані } 3 \\
\text { використанням } \\
\text { лапаротомії }(n=52)\end{array}$ & $42,8 \pm 4,7$ & $46,5 \pm 7,1$ & $39,3 \pm 10,7$ & $39,3 \pm 3,6$ & $45,7 \pm 5,7$ & $21,4 \pm 7,2$ & $43,4 \pm 3,5 *$ \\
\hline $\begin{array}{l}\text { Оперовані з } \\
\text { використанням } \\
\text { міні-інвазивних } \\
\text { методик }(\mathrm{n}=27) \\
\end{array}$ & $58,3 \pm 3,6$ & $64,2 \pm 7,2$ & $64,2 \pm 7,1$ & $55,9 \pm 3,5$ & $61,4 \pm 4,3$ & $28,6 \pm 14,3$ & $58,6 \pm 5,1^{*}$ \\
\hline $\begin{array}{l}\text { Контрольна група } \\
(\mathrm{n}=80)\end{array}$ & $72,6 \pm 3,6$ & $85,7 \pm 3,5$ & $85,6 \pm 7,0$ & $73,8 \pm 2,4$ & $79,9 \pm 2,9$ & $85,7 \pm 14,3$ & $78,6 \pm 3,5$ \\
\hline
\end{tabular}

Примітка. ${ }^{*}$ - різниця достовірна $(\mathrm{p}<0,05)$ відносно показників контрольної групи.

Аналізуючи дані тесту NAIF у групі пацієнтів, які були оперовані з приводу гострого панкреатиту з використанням лапаротомії та з використанням міні-інвазивних методик, відмічено достовірно $(\mathrm{p}<0,05)$ зниження якості життя. У пацієнтів, які були оперовані з використанням лапаротомії, відмічено достовірно $(\mathrm{p}<0,05)$ зниження ІП до рівня $(43,4 \pm 3,5) \%$, що вказує на різке зниження якості життя. У пацієнтів, що були оперовані з використанням міні-інвазивних методик, відмічено достовірно $(p<0,05)$ зниження IП до рівня $(58,6 \pm 5,1) \%$, що вказує на помірне зниження якості життя.

Висновки. 1. Оцінка якості життя пацієнтів, які перенесли операційні втручання з при- воду гострого панкреатиту, вказує на його зниження, особливо у пацієнтів, які були оперовані з використанням лапаротомії, на відміну від групи пацієнтів із гострим панкреатитом, де віддавали перевагу міні-інвазивним операційним втручанням.

2. У хворих із гострим панкреатитом, які потребують операційного втручання, за відсутності протипоказань показане використання міні-інвазивних методик.

3. Реабілітаційні заходи у хворих на гострий панкреатит після проведення операційних втручань повинні проводитись комплексно з максимальним досягненням конструктивної психологічної адаптації. 


\section{З ДОСВІДУ РОБОТИ}

\section{СПИСОК ЛІТЕРАТУРИ}

1. Бойко В. В. Диагностика и хирургическое лечение инфицированного панкреонекроза / В. В. Бойко, Ю. В. Иванова, Е. В. Мушенко // Здоров’я України. - 2012. - № 4. - С. 26-29. 2. Кугаев М. И. Взаимосвязь патоморфологических изменений в головке поджелудочной железы с интенсивностью болевого синдрома и качеством жизни / М. И. Кугаев, А. Т. Щастный, И. В. Самсонова // Новости хирургии. - 2011. - Т. 19, № 2. - С. 31-36.

3. Панкреатит : монография / [Н. В. Мерзликин, Н. А. Бражникова, В. Ф. Цхай и др.] ; под ред. Н. В. Мерзликина. - М. : ГЭОТАР-Медиа, 2014. - 528 с.

4. Пушкарев А. Л. Методика оценки качества жизни больных и инвалидов : метод. рекомендации / А. Л. Пушкарев, Н. А. Аринчина. - Минск, 2000. - 25 с.

5. Удосконалені алгоритми діагностики та лікування гострого панкреатиту : метод. рекомендації / за ред. П. Д. Фомі- на. - K., 2012. - 80 с.

6. Шекманов М. Г. Тип відношення до захворювання та його зв’язок з інтрапсихічними патернами у пацієнтів із хронічним вірусним гепатитом / М. Г. Шекманов // Медична психологія. - 2012. - Т. 7, № 4. - С. 20-25.

7. Ince A. T. Pathophysiology, classification and available guidelines of acute pancreatitis / Ali Tüzün İnce, Birol Baysal // Turk. J. Gastroenterol. - 2014. - Vol. 25, № 4. - P. 351-357.

8. Necrotizing Pancreatitis: A Review of Multidisciplinary Management / A. Sabo, N. Goussous, N. Sardana [et al.] // JOP. Journal of the Pancreas (Online). - 2015. - Vol. 16, № 2. - P. 125135. - Режим доступу до журн. : http://www.serena.unina.it/ index.php/jop/article/view/2947/3127

9. Zerem E. Treatment of severe acute pancreatitis and its complications / E. Zerem // World J. Gastroenterol. - 2014. - Vol. 20, № 38. - P. 13879-13892. 